\title{
Comparative observations of lingualized occlusion and monoplane occlusion in the treatment of severe atrophy of edentulous mandible
}

\author{
Gyo-zin Ahn, Joon-Seok Lee* \\ Department of Prosthodontics, School of Dentistry, Dankook University, Cheonan, Republic of Korea
}

\begin{abstract}
The patient who has severely absorbed residual ridges, treatments are challenging to satisfy many factors: support, retention, stability, etc. The neutral zone or monoplane occlusion with non-anatomical tooth would be helpful to get additional retention and stability. The monoplane occlusion has been used long time because it can eliminate horizontal forces and many other advantages. The lingualized occlusion was introduced to improve chewing efficiency and esthetics. But from a stability aspect, it seems controversy between monoplane occlusion and lingualized occlusion. This case report shows the results of the treat two flat residual ridge patients using functional impression; piezography, and made 2 other dentures with monoplane and lingualized occlusion that patient can select denture. (J Dent Rehabil Appl Sci 2018;34(2):127-36)
\end{abstract}

Key words: the edentulous; complete denture; piezography; monoplane occlusion; balancing ramps; lingualized occlusion

\begin{abstract}
서론
총의치 치료의 결과는 여러가지 요소에 따라 달라질 수 있다. 여러 요소 중 충분한 지지, 유지 안정 등을 얻기 위해서는 적절한 치조골과 정확한 악간관계 등이 필요하 다. 하악 치조제 흡수가 과도하게 일어난 환자의 총의치 치료는 부족한 치조골로 지지를 충분히 얻지 못하여 유 지, 안정 또한 얻기가 어려워 많은 치과의사로 하여금 도 전이 되어왔다. 이러한 경우에는 수술을 통해 추가적인 지지나 유지를 획득할 수 있지만 환자의 전신적 요인 등 의 이유로 불가능한 경우가 많다. 그리하여 치과의사들 은 추가적인 안정을 얻기 위해 중립대 기능인상 또는 무 교두 치아의 사용으로 측방력의 제거 등을 노력해왔다.

무치악 환자들은 3 차원적 저작 주기를 보이며 구치부 의 인공치에 교두각이 존재하는 경우에는 의치를 밀어내 는 측방력이 발생하게 된다. 그리하여 Payne는 편평한
\end{abstract}

*Correspondence to: Joon-Seok Lee

Professor, Department of Prosthodontics, College of Dentistry, Dankook University, 119, Dandae-ro, Dongnam-gu, Cheonan, 31116, Republic of Korea Tel: +82-41-550-0256, Fax: +82-41-550-1975, E-mail: jseok2@hanmail.net Received: March 6, 2018/Last Revision: April 2, 2018/Accepted: April 5, 2018
치조제에서 안정을 얻기 힘들며 치조제 흡수가 과도할 수록 무교두 치아가 적응증이 된다 하였다. 그리고 하악 이 심하게 흡수된 환자에게서 양측성균형교합에 비해 설 측교두교합이 안정적이어서 설측교두교합이 더 선호된 다. ${ }^{2}$

인공치아는 교두경사에 따라 해부학적 치아, 비해부학 적 치아, 반해부학적 치아로 나뉘어진다. 비해부학적 치 아를 이용한 단일평면교합은 비정상적 악간관계에 사용 이 가능하고 자유로운 하악 움직임을 허용하고 측방력 을 제거할수 있으며 인공치 배열이 쉽고 지지조직을 보 존하여 균일한 인공치 마모로 장기간 사용할 수 있다는 장점이 있다. ${ }^{3}$ 설측교두교합은 상악에는 해부학적치아를 하악에는 반해부학적 또는 비해부학적 치아를 사용하며 상악의 구개측 교두만이 하악의 교합면에 접촉하는 것을 의미하며 해부학적 치아와 비해부학적 치아의 장점을 모 두 가져왔다. ${ }^{4}$

Copyright@ 2018 The Korean Academy of Stomatognathic Function and Occlusion. (c) It is identical to Creative Commons Non-Commercial License. 
두 교합양식 모두 측방력을 최소화 했다는 장점이 있 어 과도한 하악 치조제 흡수를 보이는 환자에게 적응증 이 될 수 있지만 두 교합 양식 중 어떤 교합 양식이 바람 직할지 선택하기는 어려웠다. 본 증례에서는 과도한 하 악 치조제 흡수를 보이는 환자에게서 단일평면교합과 설 측교두교합 2 개의 총의치를 제작하여 환자에게 비교선 택하도록 함으로써 심미적, 기능적으로 양호한 결과를 얻었기에 이를 소개하고자 한다.

\section{증례보고}

\section{1. 증례 $A$}

첫 번째 증례는 당시 61세 여성 환자로 정신 질환을 않 고 계시며 2년간 임시 틀니로 생활하셨고 최종 틀니를 만 들고 싶다는 주소로 본원에 내원하였다. 임상적 검사 결 과 양악 무치악이었으며 하악 치조골 흡수가 진행되어 편평한 치조제, 큰 이결절과 미약한 조직증식이 관찰된다 (Fig. 1). 그리고 방사선학적 검사 결과 하악은 과도한 골 흡수로 기저골 밖에 남지 않았으며 이공이 치조정에 위 치하고 있었다(Fig. 2).

환자분은 비용 또는 수술의 거부감으로 임플란트 식립 을 원하지 않으셨고 과도한 하악 잔존치조제 흡수로 인 한 지지면적 부족을 고려하여 piezography 채득을 통해 단일평면교합과 설측교두교합 의치 두 쌍을 제작하기로 결정하였다.

기존에 2 년간 사용중인 임시의치의 상태는 양호하였으 며 연성 이장재(Coe-Comfort, GC Corp., Tokyo, Japan) 로 이장하여 사용하였다. 통상적인 방법으로 예비 인상 을 채득하고 개인트레이를 제작하였다. 하악 압박 인상 을 위해 컴파운드 왁스(Peri compound, GC Corp)로 모
형상에 미리 모양을 형성해 두고 항온수조를 이용해 균 일하게 연화시킨 후 구강내에서 변연 형성을 한 후 부가 중합형 실리콘 인상재(Exadenture, GC Corp)로 최종인 상을 채득하였다. 채득된 인상체에 4형 치과용 석고(Fuji rock EP, GC Corp.)로 주모형을 제작하였다. 그리고 두 개의 의치 제작을 위해 실리콘인상재(Honigum, DMG Corp., Hamburg, Germany)를 이용하여 주모형을 복제 하였다.

주모형 상에서 트레이용 자가중합 레진(Quicky resin, NISSIN, Kyoto, Japan)을 사용하여, 상악은 일반적인 방 식의 기초상과 왁스 교합제를 제작하였으며, 하악은 두 종류의 기초상을 제작하였다. 하나는 일반적인 방법으로 왁스 교합제를 올려 교합고경과 악간관계를 채득할 수 있게 하였으며, 다른 하나는 구강 내 운동시 방해 받지 않도록 통상 제작하는 기초상보다 변연을 $1 \mathrm{~mm}$ 정도 짧 게 제작하였고, 왁스교합제를 올리지 않아 piezography 채득 시 사용할 수 있게 하였다.

환자 내원시 통상적인 방법으로 교합고경을 결정하고 상하악 교합제를 조절한 뒤 중심위를 채득하고 안궁이 전을 시행하였다. 그리고 제작한 하악 기초상에 접착제 (Exaflex adhesive, GC Corp.)를 바르고 부가중합형 실

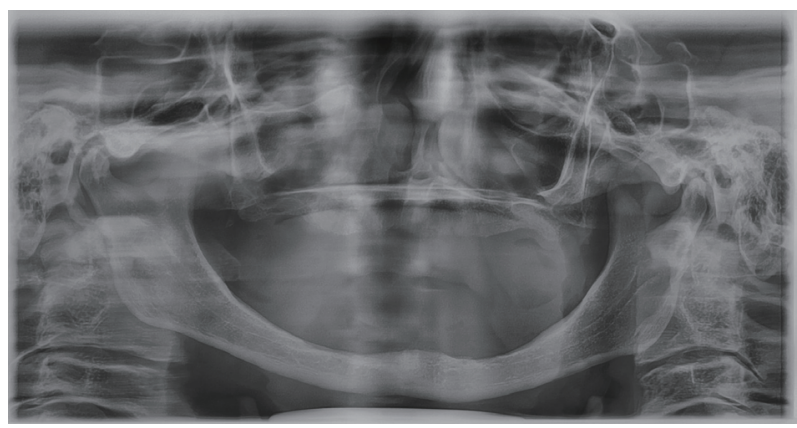

Fig. 2. Panoramic radiograph.
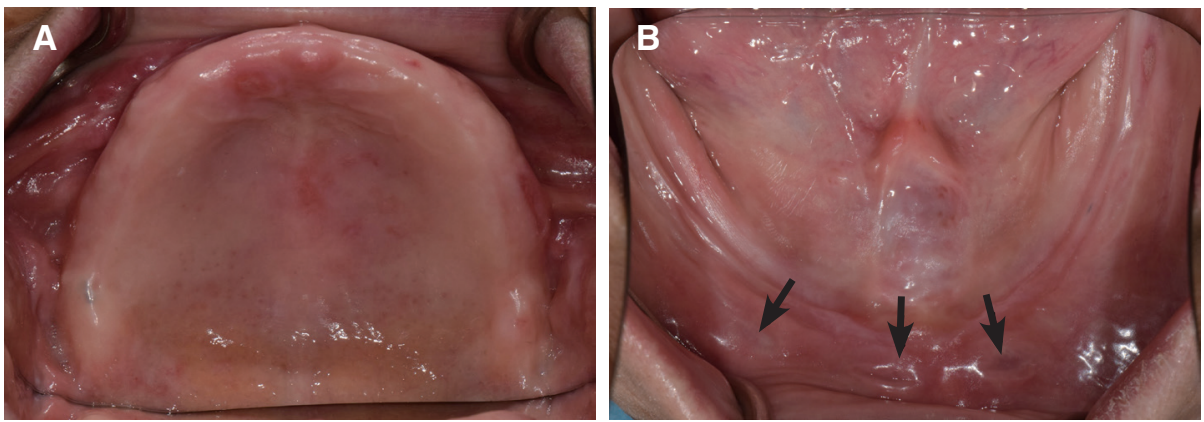

Fig. 1. Initial intra-oral photographs. (A) Maxillary occlusal view, (B) Mandibular occlusal view, severely absorbed ridges observed, arrow: flabby tissue was observed. 
리콘 인상재(Delikit fast set, HappiDEN, Seoul, Korea) 를 이용하여 'Si', 'So', 'Me', 'Te', 'De', 'Moo' 여섯 개 발 음을 반복적으로 시행하도록 하여 piezography를 채득 하였다. 중심위를 이용해 상하악 주모형을 반조절성 교 합기(Hanau ${ }^{\mathrm{TM}}$ Modular Articulator System 190, Whip Mix Corp, Port Collins, USA)에 마운팅하였다. 채득한 piezography는 실리콘 퍼티인덱스(Silagum, DMG Corp.) 를 이용해 추가 교합제를 제작하고 조절하였다. 그 결과 piezography를 통해 제작한 교합제는 해부학적 지표를 기 준으로 만든 교합제에 비해 수평피개가 눈에 띄게 증가하 였다(Fig. 3).

치아 배열은 piezography를 이용한 교합제에 통상적인
하악법의 순서를 따랐다. 하악 전치를 우선적으로 배열 후, 상악 전치를 배열하고 하악 구치에는 무교두 치아 제 품(Endura Zero, SHOFU, Kyoto, Japan)을 이용하여 설측 교두교합으로 통상적인 방법으로 인공치를 배열하였다.

납의치 시적 과정에서 인공치 배열 및 교합관계를 최종 확인하여 환자의 동의를 얻었다. 만족한 설측교두교합 납의치의 상하악 전치부 퍼티인덱스를 제작하였다. 복제 한 주모형에 퍼티인덱스를 이용하여 동일한 전치부 인공 치를 배열하고 구치부는 단일평면교합으로 무교두 구치 를 배열하였다(Fig. 4). 대구치는 상 하악 제1대구치까지 배열하였고 편심위에 3점 교합을 획득하기 위하여 하악 제2대구치 위치에 balancing ramps를 형성하였다.
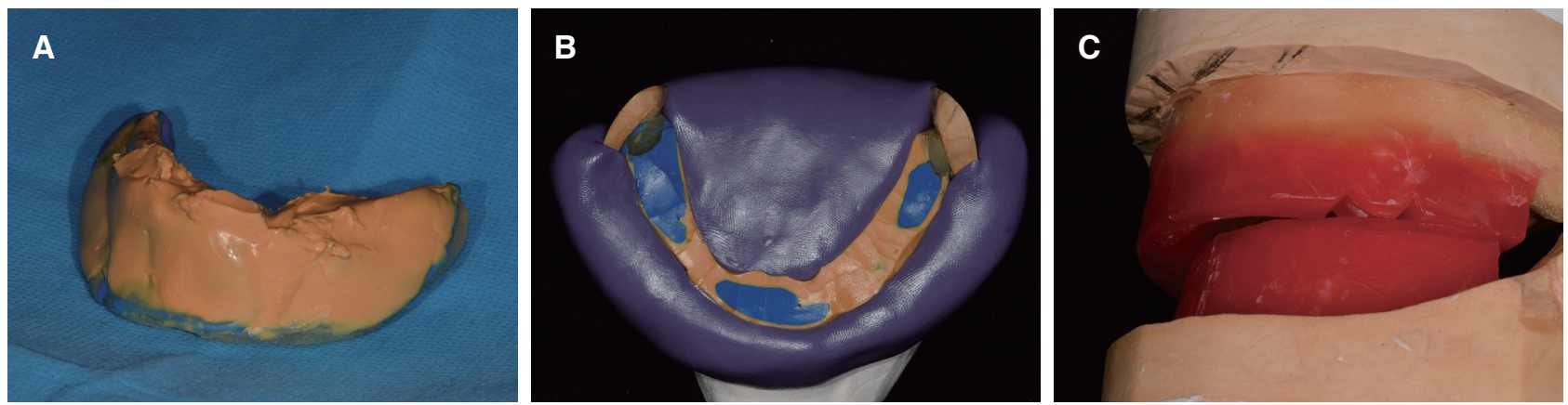

Fig. 3. Taking piezography. (A) After taking piezography by PVS impression material, (B) Putty idex for wax rim, (C) Increased overjet after piezography.
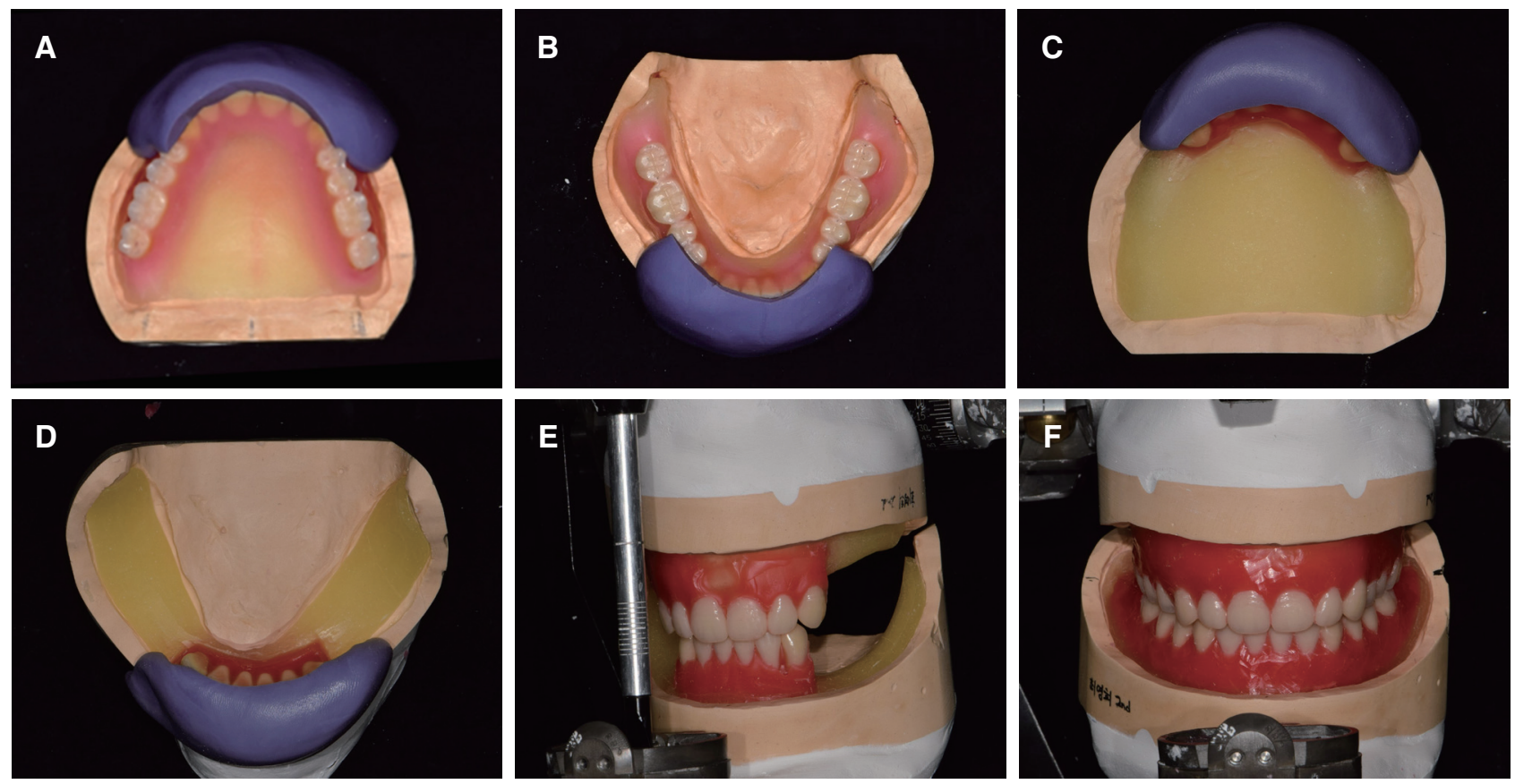

Fig. 4. Denture duplication using putty index. (A) Putty index of upper anterior teeth, (B) Putty index of lower anterior teeth, (C) Arrangement upper anterior teeth by putty index on $2^{\text {nd }}$ denture base, (D) Arrangement lower anterior teeth by putty index on $2^{\text {nd }}$ denture base, (E) After mounting upper and lower cast, (F) Arrangement molar teeth by monoplane occlusion. 
두개의 최종의치는 열중합 의치상 레진(Lucitone 199, Dentsply, York, USA)을 가압주형법으로 전입하여 중합 및 완성 하였으며 기공실 재부착을 통해 중합 오차를 제 거하였다. 최종 장착시 교합관계를 재 채득하여 진료실 재부착을 통해 교합조정을 하였다.

먼저 단일평면교합 의치를 장착하였고 3 주간 사용한 후 설측교두교합 의치를 장착하였다(Fig. 5, 6). 설측교두
교합 의치 또한 3주간 장착 하고 의치를 비교하는 설문 조사를 통해 원하는 의치를 선택하도록 하였다. 환자분 은 편안함, 안정, 저작효율, 통증, 발음, 심미에서 단일평 면교합 의치와 설측교두교합 의치 모두 우수하다고 하였 다(Table 1). 최종적으로는 두 의치 모두 편하고 좋아 두 개의 의치 모두 쓰겠다고 하며 만족스러운 결과를 보였 다.
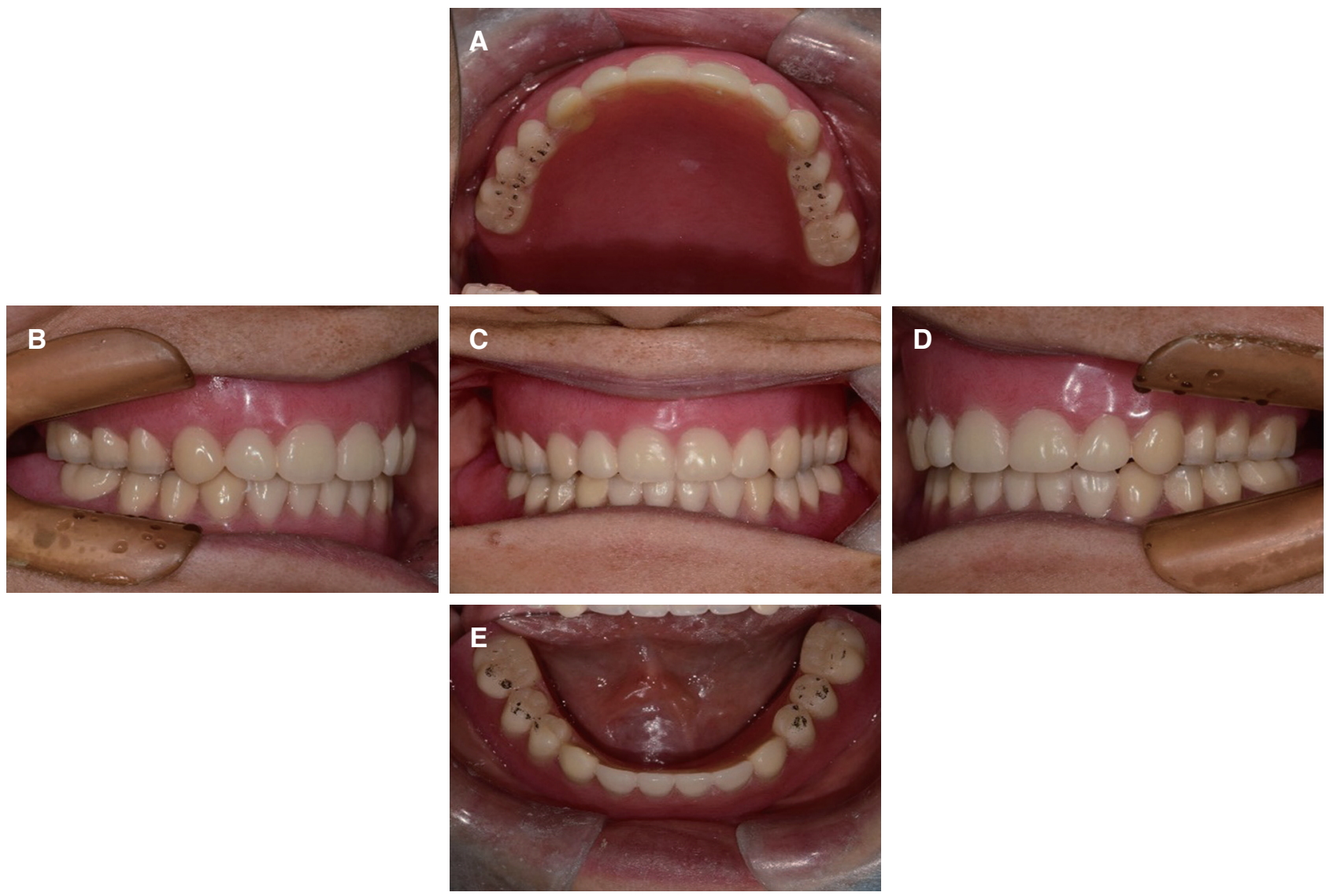

Fig. 5. Monoplane occlusion definitve denture delivery. (A) Maxillary occlusal view, (B) Lateral view (Right), (C) Frontal view, (D) Lateral view (left), (E) Mandibular occlusal view.

Table 1. Reactions to the use of two sets of dentures

\begin{tabular}{clc}
\hline & Patient 1 & Patient 2 \\
\hline Comfort & Prefer M and L & Prefer L \\
Stability & Prefer M and L & Prefer M and L \\
Mastication & Prefer M and L & Prefer L \\
Pain & Prefer M and L & Prefer M and L \\
Speaking & Prefer M and L & Prefer M and L \\
Esthetic & Prefer M and L & L \\
\hline
\end{tabular}

M: monoplane occlusion denture; L: lingualized occlusion denture. 

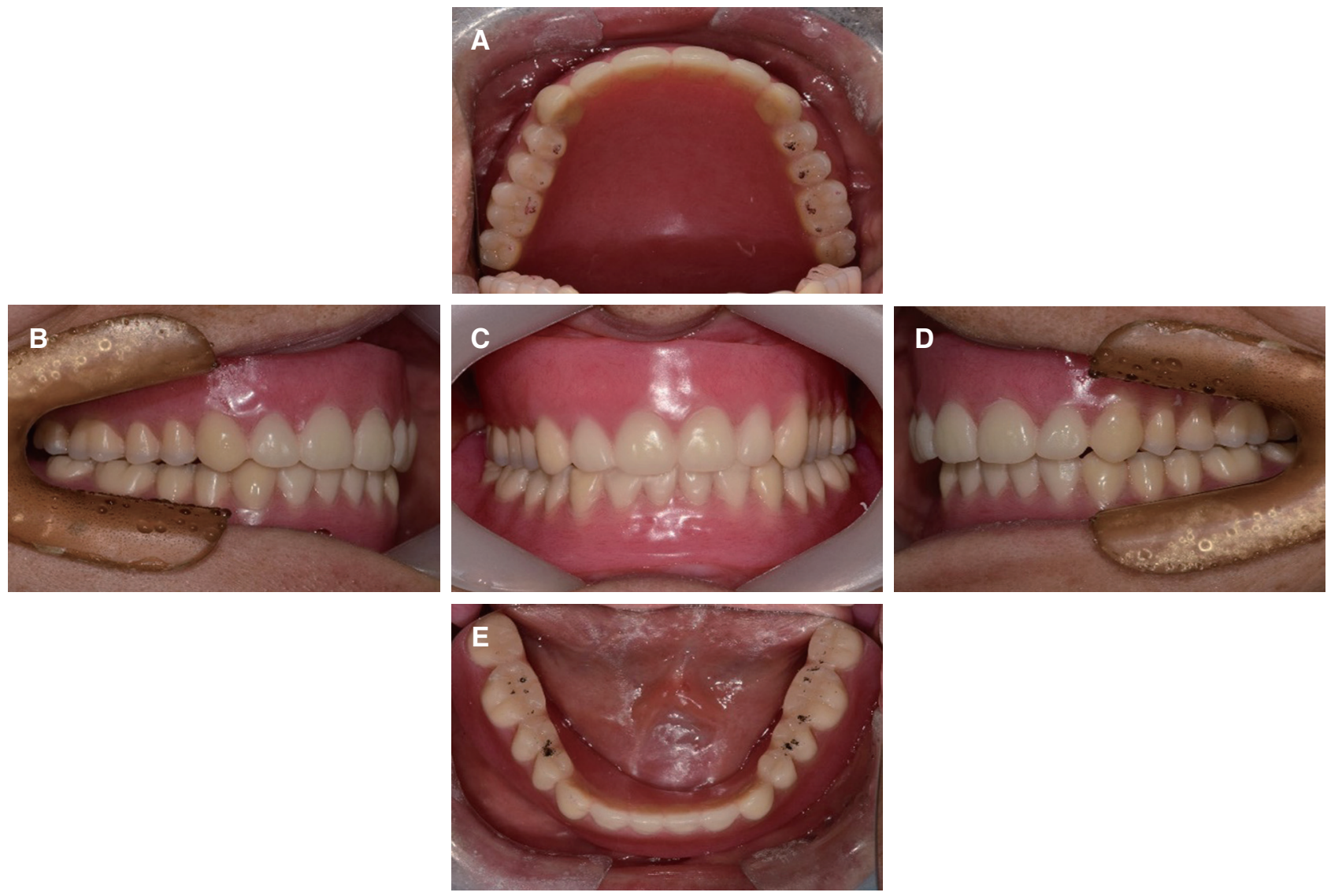

Fig. 6. Lingualized occlusion definitve denture delivery after 3weeks. (A) Maxillary occlusal view, (B) Lateral view (Right), (C) Frontal view, (D) Lateral view (left), (E) Mandibular occlusal view.

\section{2. 증례 $B$}

두 번째 증례는 74세 남성 환자로 14년 전에 제작한 의 치가 불편하여 새로 제작하고 싶다는 주소로 본원에 내 원하였다. 당뇨약을 먹고 있었고 기타 의과적 병력은 없 었다. 임상적 및 방사선적 검사 결과 하악 좌측 제 3 대구 치 잔존치근이 존재하였고 하악의 근육 부착부가 높았
다(Fig. 7). 기존 사용 의치는 인공치가 심하게 마모되어 있었으며 교합 시 활주를 보이며 정중선이 틀어져 있었 다.

하악의 높은 근육 부착부와 과도한 잔존치조제 흡수 로 인한 지지면적 부족을 고려하여 이전 환자와 같이 piezography 채득을 통해 단일평면교합과 설측교두교합 의치 두 쌍을 제작하기로 결정하였다.
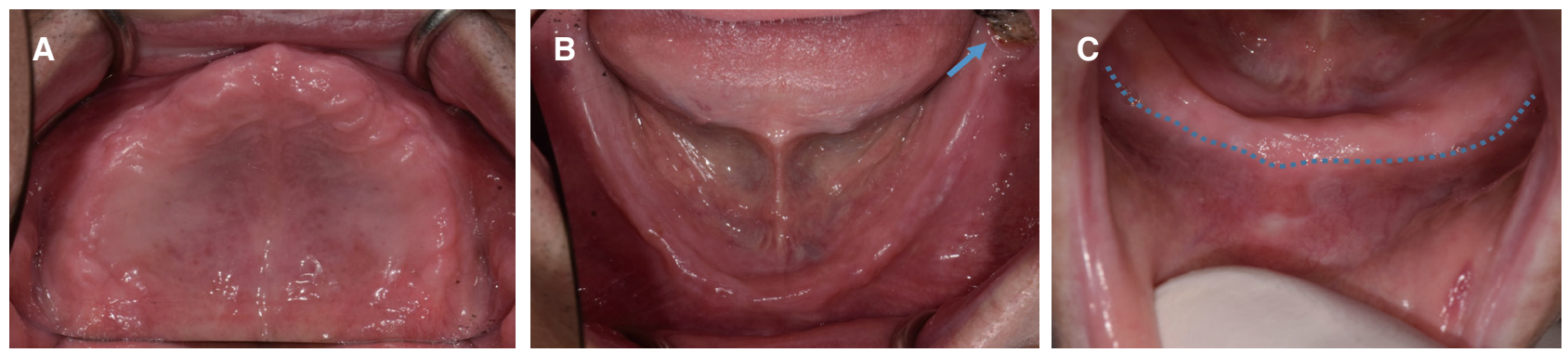

Fig. 7. Initial intraoral photographs. (A) Maxillary occlusal view, (B) Mandibular occlusal view, arrow: Lower left $3^{\text {rd }}$ molar, (C) Lower ridge point on high muscle attachment. 
하악 좌측 제 3 대구치 잔존치근은 발치하고 기존에 14 년간 사용한 틀니는 중심위 유도를 통해 아크릴 레진으 로 수직고경을 높여주어 의치의 활주를 방지하였고 연 성 이장재(Coe-Comfort, GC Corp.)로 이장하여 사용하 였다. 첫번째 증례 환자와 같은 과정으로 예비 인상 채 득 후 개인트레이 제작을 통해 최종인상을 채득하였고 piezography를 시행하였다. Piezography 결과 해부학적 지표 기준의 교합제와 크게 차이 나지 않았다. 기존의 교 합제는 마운팅 후 제거하고 piezography를 이용한 교합
제에 설측교두교합으로 통상적인 방법으로 인공치를 배 열하고 납의치 시적을 시행하였다. 같은 방법으로 의치 복제를 통해 단일평면교합 의치를 제작하였다(Fig. 8). 두 의치를 중합 및 완성 후 최종 장착시 교합관계를 재 채득 하여 진료실 재부착을 통해 교합조정을 시행하였다.

이번에는 먼저 설측교두교합 의치를 장착하였고 3 주 간 사용한 후 단일 평면 교합 의치를 장착하였다(Fig. 9, 10). 단일평면교합 의치 또한 3 주간 장착 하고 의치를 비 교하는 설문조사를 통해 원하는 의치를 선택하도록 하였
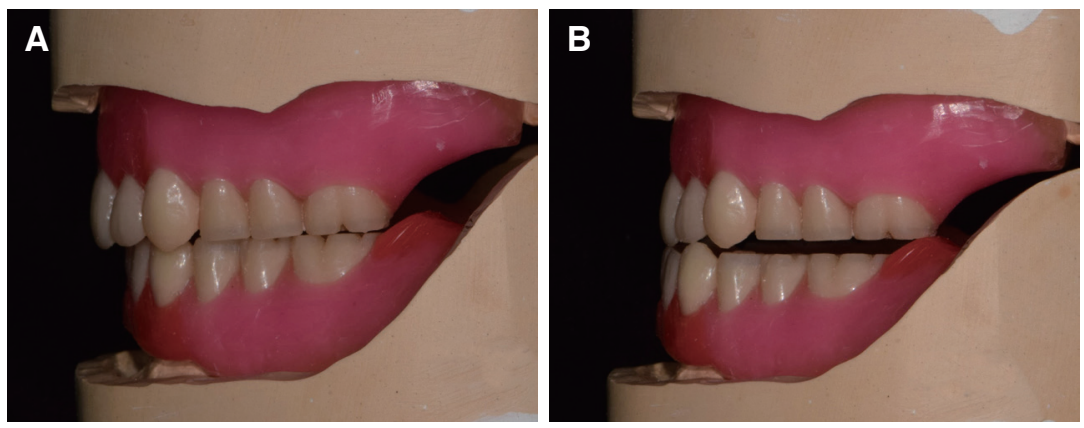

Fig. 8. Arrangement monoplane occlusion with balancing ramps. (A) Lateral view, (B) Tripodism on anterior excursion.
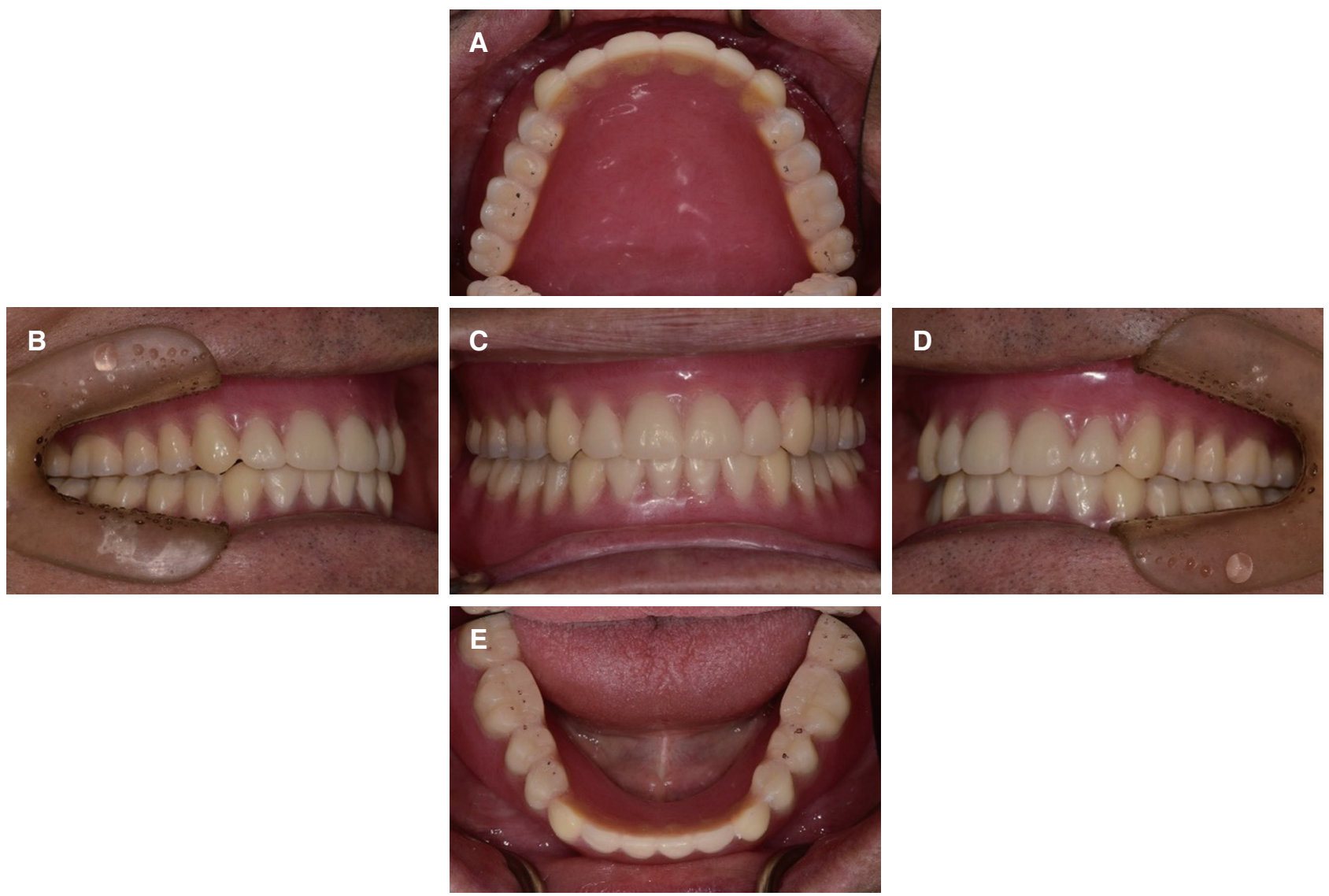

Fig. 9. Lingualized occlusion definitve denture delivery after 3 weeks. (A) Maxillary occlusal view, (B) Lateral view (Right), (C) Frontal view, (D) Lateral view (left), (E) Mandibular occlusal view. 

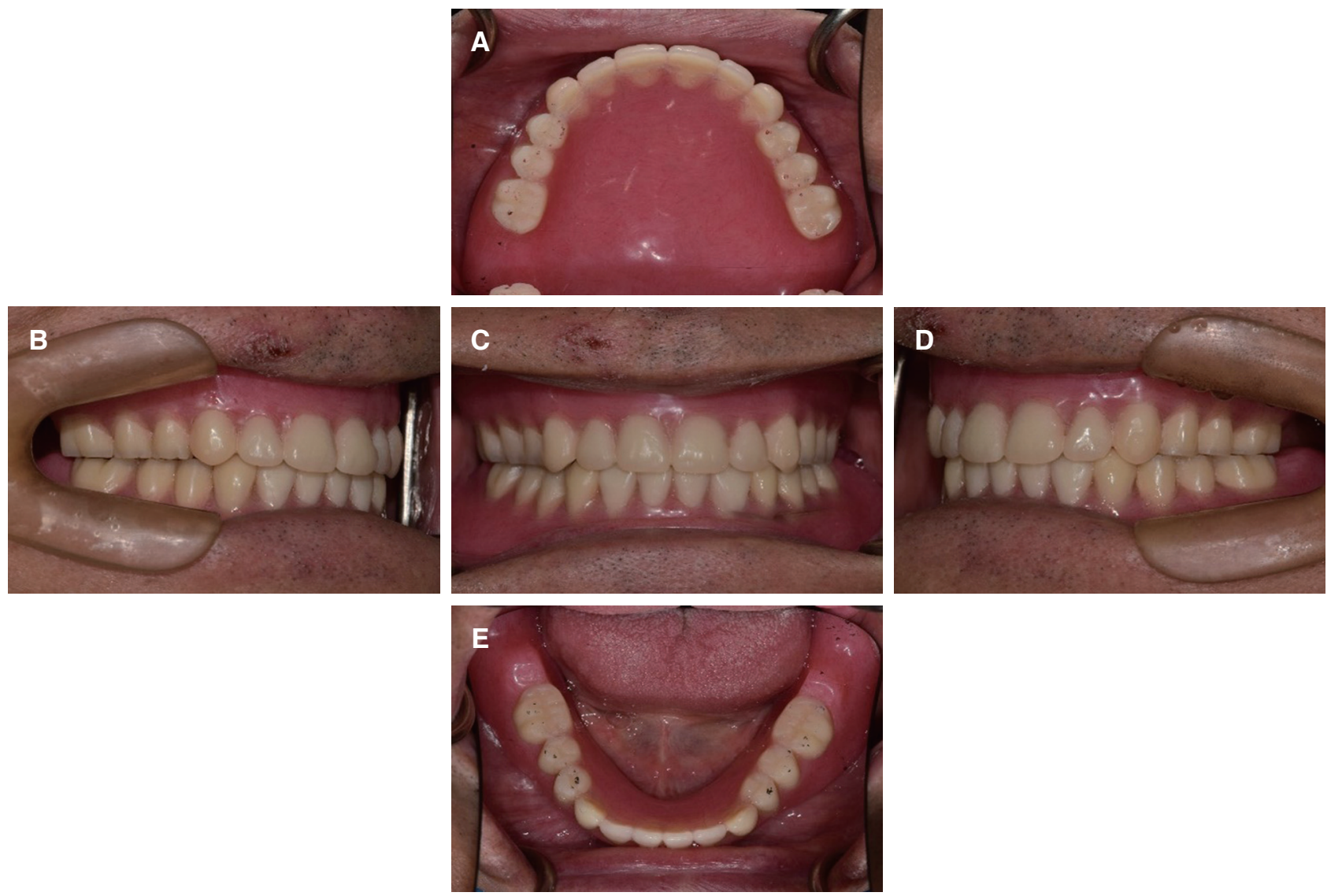

Fig. 10. Monoplane occlusion definitve denture delivery. (A) Maxillary occlusal view, (B) Lateral view (Right), (C) Frontal view, (D) Lateral view (left), (E) Mandibular occlusal view.

다. 환자분은 편안감과 저작시 통증 면에서 설측교두교 합 의치가 단일평면교합 의치에 비해 우수하다고 하였고 저작, 안정, 발음, 심미면에서는 두 의치 모두 우수하다고 하였다(Table 1). 최종적으로는 설측교두교합 의치를 선 택하며 환자분은 만족하였다.

\section{고찰}

하악 무치악 환자의 보철적 치료는 지금까지도 많은 치과의사들을 어려움에 빠지게 한다. 임플란트 술식의 발전으로 임플란트 피개의치를 제작할 수 있지만 많은 무치악 환자들은 전신적 건강 또는 경제적 여건 등으로 인해 전통적 총의치 치료를 받는 경우가 많다. 특히 이번 증례의 환자들과 같이 하악 잔존치조제가 과도하게 흡 수되어 편평한 경우에는 의치의 지지를 얻기가 어려워 유 지력을 얻기가 힘들고 치조제 사이의 악간 공간이 증가 하게 되어 의치는 측방력에 취약하게 된다. 발음을 이용
해 치아 위치를 기록하는 piezography를 이용해 중립대 를 채득 한 후 무교두 치아를 이용한 단일평면교합 의치 와 설측교두교합 의치 제작을 통해 측방력의 제거를 꾀 하였고 단일평면교합 의치와 설측교두교합 의치를 비교 하였다.

지금까지 많은 논문에서 비해부학적 치아와 해부학적 치아를 이용한 의치를 비교하였다. 그 중 많은 환자군을 비교한 Shetty ${ }^{5}$ 의 연구에 따르면 해부학적 치아의 의치를 환자가 더 선호한다고 하였고 $\mathrm{Berg}^{6}$ 의 연구에 따르면 2 년 follow-up 결과까지 비해부학적 치아의 의치와 해부 학적 치아의 의치 사이에 유사한 만족도를 보였다. 하지 만 위의 연구들은 일반적인 하악골을 가진 환자에서의 연구였고 과도한 하악골 흡수를 보이는 환자에서의 결과 는 아니었다.

무교두치아를 이용한 단일평면교합의 배열 방법은 세 가지가 있다. Flat plane 방법은 수직피개를 부여하지 못 하여 비 심미적이며 편위운동 시 의치의 탈락이 일어날 
수 있다. 다음으로 보상만곡을 부여하는 방법은 저작시 측방력이 생겨 안정성이 떨어지게 된다. 마지막으로 하 악 최후방 구치 부위에 레진 등으로 balancing ramps를 형성하는 방법은 편위운동 시 3점 교합을 부여할 수 있어 안정적이고, 전치부 수직피개를 부여하여 심미 또한 획 득할수 있다. ${ }^{7}$ 단일평면교합의 단점으로 수직 피개의 부 재 및 평편한 교합면으로 인한 낮은 심미가 있지만 이번 증례에서 하악 제 2 대구치 위치에 balancing ramps를 형 성하여 전치부의 수직 피개를 부여하고 편위 운동 시 3점 교합을 얻어 심미적, 기능적으로 우수한 결과를 보였다.

Madalli 등 ${ }^{8}$ 의 연구에서 무교두 치아는 해부학적 치아 의 설측교두교합 및 양측성 균형 교합에 비해 치조제에 힘이 고루 분산되어 낮은 압력 값을 보인다. 하지만 Sutton 등 ${ }^{9}$ 의 연구에서 무교두 치아는 해부학적 치아에 비해 저작효율이 낮으며 무교두 치아 의치 사용시 더 높은 저 작근의 활성을 보이게 되어 치조제에 더 높은 압력이 가 해진다고 하였다. 본 증례의 첫번째 환자는 저작 효율 및 통증에서 차이가 없었고 두번째 환자의 경우 음식물 저 작 효율에 대해서는 차이를 느끼지 못했지만 저작시 단 일평면교합 의치가 설측교두교합 의치에 비해 통증이 발 생한 것은 더 높은 근육 활성의 결과로 사료된다.

다른 교합관계를 갖는 두 개의 의치 제작을 위해 납의 치 시적 후 퍼티인덱스를 이용해 상하 전치부 관계를 복 제하여 구치부 인공치 배열을 달리 하였다. 이를 통해 동 일한 전치부 심미를 획득하며 구치부 교합 관계만을 변 화시켜 구치부 교합 관계의 변화에 따른 환자 만족도를 비교할 수 있었다.

중립대 위치를 채득하기 위한 piezography는 연하 및 저작 운동을 이용하는 일반적인 중립대 채득 방법보다 는 발음을 통해 근육의 수평적 힘을 주로 사용하게 되어 의치의 안정을 획득하는데 효율적이다. ${ }^{10}$ 대신 수직고경 은 결정해 주지 못하기 때문에 중심위 채득을 위한 추가 적인 기록상 및 교합제의 제작이 필요하다. 첫 번째 환자 의 경우 piezography 채득 후 전치부에서 해부학적 지표 를 기준으로 제작한 기존 교합제에 비해 약 $3 \mathrm{~mm}$ 정도 후방으로 이동하였다. 발음 및 심미를 고려하면 상하악 전치부에 과도한 수평피개를 피해야 하지만 하악 의치의 안정을 우선시 하여 상악 전치부는 제 위치에 두며 약 5 $\mathrm{mm}$ 정도의 overjet을 부여하였다. 그 결과 두 종류의 의 치 모두 우수한 심미 및 안정을 보였다. 두 번째 환자의 경우 기존 교합제와 piezography 채득 후에 큰 차이가 없 었고 역시 우수한 안정을 획득하였다.
과도한 하악골 흡수를 보이는 환자에게서 단일평면교 합 의치는 설측교두교합 의치와 비교하여 충분히 만족할 만한 결과를 보였다. Class II와 Class III의 악간 관계 또 는 파킨슨 환자와 같은 운동 장애로 인해 정확한 악간 관 계 채득이 어려운 경우에 단일평면교합 의치는 안정 심미 등에서 심미적 또는 기능적으로도 만족할만한 치료 선택 이 될 것으로 사료된다.

\section{결론}

과도한 하악골 흡수를 보이는 두 명의 환자에게서 단 일평면교합 의치와 설측교두교합 의치를 3주 씩 모두 장 착시켜 보며 환자의 만족도를 비교해 보았다. 첫번째 환 자의 경우 편안감, 안정감, 저작효율, 통증, 발음, 심미에 서 두 종류의 의치 만족하였고 두 번째 환자의 경우 단일 평면교합 의치에서 저작 시 통증이 더 발생하였지만 나머 지 항목에 대해서는 두 교합 관계 의치 모두 만족하였다. 여기서 주목할 만한 건 단일평면교합 의치의 비심미적인 단점을 balancing ramps를 통해 수직피개를 부여하며 우 수한 전치부 심미를 획득하였고 저작 효율에서 단일평면 교합 의치가 설측교두교합 의치와 유사한 만족도를 보 였다는 것이다. 그리고 과도한 하악골 흡수로 해부학적 지표를 알아보기 어려운 경우 piezography를 이용한 중 립대 위치에 인공치를 배열하여 부가적인 안정을 획득할 수 있었다.

과도한 하악골 흡수를 보이는 환자에게 전통적 총의치 치료를 하는경우 piezography를 이용한 중립대 위치에 단일평면교합 또는 설측교두교합을 사용하는 것은 보다 안정적이며 기능적으로 우수한 의치 제작을 가능하게 할 것으로 사료된다.

\section{ORCID}

Gyo-zin Ahn https://orcid.org/0000-0001-9400-355X Jun-seok Lee https://orcid.org/0000-0002-3709-1386

\section{References}

1. Payne SH. A comparative study of posterior occlusion. J Prosthet Dent 1952;2:661-6.

2. Matsumaru Y. Influence of mandibular residual ridge resorption on objective masticatory measures 
of lingualized and fully bilateral balanced denture articulation. J Prosthodont Res 2010;54:112-8.

3. Jones PM. The monoplane occlusion for complete dentures. J Am Dent Assoc 1972;85:94-100.

4. Phoenix RD, Engelmeier RL. Lingualized occlusion revisited. J Prosthet Dent 2010;104:342-6.

5. Shetty NS. Comparative observations of the use of cusp and zero-degree posterior teeth. J Prosthet Dent 1984;51:459-60.

6. Berg E. The influence of cusped and cuspless teeth on patient satisfaction with complete dentures. A 2-year follow-up study. J Dent 1988;16:269-76.

7. Nimmo A, Kratochvil FJ. Balancing ramps in nonanatomic complete denture occlusion. J Prosthet
Dent 1985;53:431-3.

8. Madalli P, Murali CR, Subhas S, Garg S, Shahi P, Parasher P. Effect of occlusal scheme on the pressure distribution of complete denture supporting tissues: an in vitro study. J Int Oral Health 2015;7: 68-73.

9. Sutton AF, McCord JF. A randomized clinical trial comparing anatomic, lingualized, and zero-degree posterior occlusal forms for complete dentures. J Prosthet Dent 2007;97:292-8.

10. Ikebe K, Okuno I, Nokubi T. Effect of adding impression material to mandibular denture space in Piezography. J Oral Rehabil 2006;33:409-15. 


\section{심한 하악 치조골 흡수를 보이는 환자에서 설측 교두 교합과 단일평면 교합을 비교 관찰한 의치 수복 증례}

안교진, 이준석*

단국대학교 치과대학 치과보철학교실

치조골 흡수가 심한 무치악 환자에서는 지지의 부족으로 유지, 안정 등의 요인을 갖추기 어렵다. 이에 추가적인 유지와 안 정의 획득을 위한 노력으로 중립대의 이용 또는 단일평면교합 형성이 있다. 단일평면교합은 수평력의 제거 등 장점이 있 어 오랜기간 이용되었다. 그리고 여기에 저작 효율과 심미성을 개선시키기 위해 설측교두교합이 제시되었다. 하지만 안정 성 면에서는 단일평면교합과 설측교두교합 사이에 여전히 논란이 있다. 본 증례는 하악 치조골의 과도한 흡수에 의해 편 평한 치조제를 보이는 두 환자로, piezography를 이용하여 기능 인상을 채득하고 단일평면교합과 설측교두교합의 의치를 각각 제작함으로써 환자에게 의치를 비교 선택할 수 있도록 하여 환자의 만족도를 높였기에 이를 보고하는 바이다.

(구강회복응용과학지 2018;34(2):127-36)

주요어: 전부 무치악; 총의치; piezography; 단일평면교합; balancing ramps; 설측교두교합

*교신저자: 이준석

(31116) 충남 천안시 동남구 단대로 119 단국대학교 치과대학 치과보철학교실

Tel: 041-550-0256 | Fax: 041-550-1975 | E-mail: jseok2@hanmail.net

접수일: 2018년 3월 6일 | 수정일: 2018년 4월 2일 | 채택일: 2018년 4월 5일 